\title{
Just another Brick in the Wall?* A Swiss Report on the use of Computerized Textual Elements in Substantiating Negative Asylum Decisions
}

WALTER KÄLIN†

\begin{abstract}
The principle of due process requires that reasons be given for rejecting a nonnational's request for asylum. One measure to achieve a faster, more efficient, and at the same time more uniform output of asylum decisions in Switzerland has been the introduction of so-called Textbausteine, standardized and computer-stored paragraphs, or textual elements, which can be combined with phrases and paragraphs drafted with specific reference to the individual case in negative decisions. Many such standardized paragraphs simply quote legal provisions, or contain introductory or closing phrases and sections common to many decisions. This article looks at those textual elements that do pose serious problem, in particular where they construe legal terms and provisions, and/or apply them to common factual situations. It is suggested that they are not just a helpful device to facilitate the drafting of negative decisions; any collection of standardized textual elements has to be well-balanced and complete, in order to be acceptable. This means that examples of positive criteria, sufficient for the grant of asylum, must be included, as well as negative examples.
\end{abstract}

\section{The Problem}

The principle of due process requires that reasons be given for rejecting a non-national's request for asylum, and in Switzerland, the competent

- Roger Waters. (C) Pink Floyd Music Publishers Lid.

$\dagger$ Prof. Dr iur., LI..M. Professor, Faculty of Law, University of Bern, Switzerland. 
authorities are obliged to substantiate negative (but not positive) asylum decisions in writing. ' The growing number of both asylum applications and negative decisions in recent years ${ }^{2}$ has necessitated rationalizations in the decision-making process, especially for the authority at first instance, the Office of the Delegate for Refugees.

One measure to achieve a faster, more efficient, and at the same time more uniform output of asylum decisions at this level has been the introduction of so-called Textbausteine, ${ }^{3}$ that is, standardized and computer-stored paragraphs, or textual elements, which the official can combine with phrases and paragraphs drafted personally for the individual case, when developing the reasons for negative decisions. At present, more than one hundred and fifty such standardized textual elements exist, though they' do not cover all aspects of an asylum decision. Many such standardized paragraphs simply quote legal provisions, or contain introductory or closing phrases and sections common to many decisions. These textual elements do not pose any serious problem. The opposite is true, however, for Textbausleine construing legal terms and provisions, and/or applying these constructions to common factual situations. ${ }^{+}$

These law-construing Textbausleine have provoked discussion, not only because some of them reflect very restrictive legal positions, ${ }^{5}$ but also because their use is, according to one view, problematic in principle. Are they, as has been maintained by the authorities, just a helpful device which facilitates the drafting of negative decisions, and has no legal implications? Or are the critics of present asylum policy right, who claim that these Textbausteine contribute to a restrictive practice, because they narrow the perspective of decision-makers, and are thus just another brick in the wall being built up in Europe to keep refugees out? What is their legal character? Can the collection of these standardized textual elements be kept confidential, as is the case today, or should they be published? How should they be shaped, in order to fulfil the requirements of procedural fairness?

These questions were the topic of a recent report by the Commission de

1 Article 35, Federal Act on Administrative Procedure (Bundesgesetz über das Vereralluagsverfarhren vom 20.12.1968, SR 172.021).

2 In 1987, the Office of the Delegate for Refugees made 11,239 decisions, of which 8,292 were negative.

'Textual building blocks,' in literal translation.

+ For example, article 8 of the Swiss Asylum Act (Loi sur l'asile du 5 oct. 1979: FF 1979 II 977 , Asjlgesetz vom 5 Okt. 1979: BBI 1979 II 993) provides that asylum is not accorded to a person who appears unworthy by reason of reprehensible activities (en raison d'actes répréhensibles/uregen veruerficher Handlungen). One of several Textbausteine to article 8 defines the term 'reprehensible activities', and provides that any person is unworthy of asylum who has committed a crime in the sense of article 9 of the Swiss Penal Code, regardless of the penalty actually imposed.

3 This aspect is not discussed in the present note See, however, remarks in Bencht der Geschäflsprüfungscommission, Amtliches Bulletin Nationalrat 1987, 755. 
gestion, a standing committee of the Swiss Parliament charged with supervising and inspecting the administration. ${ }^{6}$ The report did not challenge the admissibility of computer-stored, standardized textual elements in principle, but nevertheless reached some innovative and far-reaching conclusions.

\section{The Legal Character of Law-construing 'Textbausteine'}

Although the law-construing standardized textual elements do not just quote precedents, or reflect what is already written in the law, they do contain rules of general application. Unlike rules of law, however, these rules are not enacted by Parliament, or as executive or ministerial ordinances; instead, they are drafted by a working group in the Office of the Delegate for Refugees and approved by senior officials of the Office whenever the need arises. No hearings or other form of outside participation in the drafting process take place. What, then, is the legal character of such Texibausteine?

The federal administration maintained that even law-construing textuai elements are mere drafting aids, without any legal meaning. The Committee, accepting the findings of an expert opinion by the author of this note, did not share this view, but qualified them as 'administrative ordinances with external effect'. ' This notion has its origins in German administrative law. It denotes legal rules of general application, enacted within an administrative unit nol in order to guide directly the behaviour of persons outside the administration, but to oblige officials to apply the law in a certain uniform way. In principle, their binding force unfolds only within the administration, but de facto they indirectly manifest external effects by guiding the official when deciding on the rights and duties of individuals. However, unlike 'real' laws, they are not directly addressed to the individuals concerned and do not bind them in any way. On this basis, it is argued that those outside the administration do not need to know such rules; as a consequence, they do not have to be published, although the authorities may choose to do so. ${ }^{8}$

\footnotetext{
- Rapport de la Commission de gestion du 18 nov. 1987 , Exigences de nature juridique auxquelles doivent répondre les éléments de texte, FF 1988 II 694 (French version); Bericht der Geschäfisprüfungskommission vom 18 Nov. 1987, Rechtliche Anforderungen an Textbausteine, BBI 1988 II 708 (German version).

7 In German: Verwaliangsverordnung mil Aussenwirkung; in French: instruction de seroice applicable à des tiers.

${ }^{B}$ For details, see Kälin, W, 'Rechtlıche Anforderungen an die Verwendung von Textbausteinen für die Begründung von Verwaltungsverfügungen,' Zeitschnft für Sehweizerisches Recht, Band 107, 1988, I. Halbband, 400.
} 


\section{Public access}

The Delegate for Refugees has chosen not to publish the collection of standardized textual elements, and refuses to allow access to them, even for asylum-seekers and their lawyers during the procedure. The Delegate fears that their publication would facilitate the fabrication of false asylum claims, and for procedural reasons, because Swiss law does not know any equivalent to the United States Freedom of Information or other equivalent legislation, this view cannot be challenged by making an appeal to a court.

The parliamentary Committee used the concept of administrative ordinance to justify its recommendation to publish the collection of Textbausteine, or to allow access at least to persons actually involved in an asylum procedure. 'The report correctly stresses that asylum-seekers have the right to be treated according to the same rules as are applied in other cases, and that a decision in disregard of an administrative ordinance constitutes unequal treatment. As a rejected asylum-seeker would be unable to challenge such violation of a constitutional right, ${ }^{9}$ if he or she had no knowledge of the relevant content of the administrative ordinance, access is a necessary prerequisite for effective use of the right to appeal to a higher instance. ${ }^{10}$ This line of argument is especially persuasive in the Swiss context, because only very few asylum decisions are published; thus, it is often very hard to find out whether a particular decision is in line with established practice, or not.

The Committee rejected the argument of possible abuse, by stressing that to substantiate an appeal with convincing legal arguments could never be regarded as abusive in a State devoted to the principle of the rule of law.

\section{A Well-balanced and complete Collection of 'Textbausteine'}

The Committee explicitly acknowledged the advantages of using standardized textual elements for substantiating negative asylum decisions, and their contribution to a faster and, at the same time, more uniform asylum procedure. It noted, however, that a collection of standardized textual elements has to be well-balanced and complete, in order to be acceptable.

The investigations of the Committee revealed that the existing collection is often used as a kind of check-list for preparing decisions;

9 Equal treatment is guaranteed by article 4 of the Swiss Constitution.

10 Article 11 of the Swiss Asylum Act (above, note 4), provides only for an appeal to one higher administrative instance, the Department of Justice and Police. 
officials frequently display a tendency to search the actual case for those elements which are included in the collection, when they are interviewing asylum-seekers, and verifying the law and the facts. As existing Textbausteine are limited to negative arguments that justify the rejection of asylum requests, their use as a check-list may narrow the view of the official, and reinforce a tendency to grant asylum only if an application does not fall under any of the negative elements and arguments in the collection. The Committee therefore recommended balancing the existing collection with examples of the positive criteria sufficient for the grant of asylum.

For similar reasons, the Committee criticized the failure of the collection of Textbausleine to cover other important aspects of the asylum process; among others, it denounced the lack of detailed, standardized textual elements concerning the question, whether a rejected asylumseekers can be ordered to leave the country and be forcibly returned to his or her country of origin. The Committee was concerned that a lack of guidance in this area of law may induce officials to neglect the examination of the crucial question, whether return to the country of origin is admissible in a particular case.

\section{Conclusions}

The report addresses an important, but often neglected aspect of the asylum procedure. It manifests a conviction that check-lists and other aids provided to officials examining individual requests for asylum are of legal significance, and that a high degree of accessibility, completeness and balance in such tools is important to maintain the fairness of the asylum procedure. If they do not fulfil these criteria, they may distort the process of decision-making, and thus curtail the chances of bona fide refugees obtaining asylum.

The Swiss Federal Council (the Swiss Government) has now to comment on the recommendations of the Committee; no such answer has yet been published, but it is to be hoped that the response will be positive.

\section{Résumé}

Le principe d'un examen adéquat exige que des raisons soient avancées pour le rejet d'une demande d'asile. Pour accélérer, améliorer et uniformiser les décisions en matière d'asile prises en Suisse, on a adopté le système Texbausteine, c'est-à-dire, des paragraphes normalisés et entrés sur ordinateur pouvant être combinés avec des phrases et des paragraphes portant spécifiquement sur le cas individuel dans le cadre de décisions négatives. La plupart de ces paragraphes normalisés se contentent de citer des dispositions juridiques ou contiennent des phrases et des paragraphes liminaires ou 
de clôture communs à de nombreuses décisions. Cet article examine ces éléments textuels qui posent de graves problèmes, en particulier lorsqu'ils analysent des dispositions juridiques ou les appliquent à des situations factuelles courantes. On suggère qu'il ne s'agit pas là simplement d'un moyen de faciliter la rédaction de décisions négatives; toute compilation d'éléments textuels normalisés doit être équilibrée et complète afin d'être acceptable. Cela signifie que des exemples de critères positifs, suffisants pour l'octroi de l'asile, doivent être inclus, au même titre que les exemples négatiffs.

\section{Resumen}

El principio del proceso de acuerdo al derecho requiere que sean dadas las razones para rechazar la solicitud de asilo de un extranjero. En Suiza, una medida para lograr una adopción de decisiones sobre el asilo más rápida, más eficiente y al mismo tiempo más uniforme, ha sido la introducción del llamado Textbauskeine, que incluye párrafos normativos almacenados en computadora, otextos que pueden ser combinados con frases y párrafos redactados con referencias específicas a casos individuales en decisiones jurídicas negativas. Muchos de estos párrafos normativos simplemente citan provisiones legales, o contienen frases introductorias o de conclusión y secciones comunes a muchas decisiones jurídicas. Este articulo está enfocado hacia los textos particularmente problemáticos, en concreto cuando ellos interpretan términos legales y provisiones y/o su aplicación en situaciones básicamente comunes. Se ha propuesto que dichos textos no sean simplemente mecanismos para facilitar la redacción de decisiones juridicas negativas; cualquier recopilación de textos normativos debe ser equilibrada e integral para que sea aceptable. Esto significa que los ejemplos de criterios favorables, que sean suficientes para el otorgamiento de asilo, deben ser incluídos tanto como los ejemplos desfavorables. 